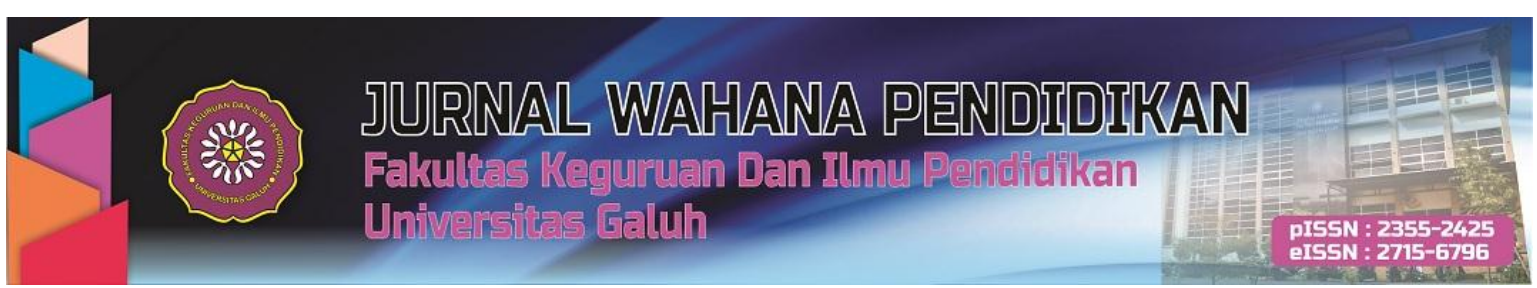

https://jurnal.unigal.ac.id/index.php/jwp

\title{
FUNGSIONALISASI SUPERVISI PENDIDIKAN UNTUK MEMBENTUK KARAKTER KEJUJURAN GURU DALAM PENINGKATAN KUALITAS PROFESI GURU DAN PEMBELAJARAN
}

\author{
Kusnandi \\ Program Studi Administrasi Pendidikan \\ Pascasarjana Universitas Galuh \\ E-mail: dc698@member.cni.co.id
}

\begin{abstract}
The quality of the performance teaching profession and the quality of learning affect the success of the teaching and learning process. Teacher honesty character will support the quality of teacher professional performance more effectively. Efforts to improve the ability to carry out the learning process require attention from the person in charge of the education system continuously, among others, through the functionalization of educational supervision. The implementation of educational supervision with standard technical strategies will be better if the function is more focused on developing the character of teacher honesty in learning. The job of a supervisor is to help, encourage, and give teachers confidence that the teaching-learning process can and must continue to be better. Supervision activities are carried out through various processes of teaching problem solving and aim to improve the effectiveness and efficiency of the teaching-learning process. Supervision is a help to the teacher in improving the teaching-learning situation. The results will be better if it focuses on internalizing the character of honesty in the teacher in carrying out the main tasks and functions in school.
\end{abstract}

Keywords: Functionality, Supervision, Honesty, Teachers, Education

\begin{abstract}
ABSTRAK
Kualitas kinerja profesi guru dan kualitas pembelajaran mempengaruhi keberhasilan proses belajar mengajar. karakter kejujuran guru akan mendukung kualitas kinerja profesi guru lebih efektif. Upaya meningkatkan kemampuan dalam melaksanakan proses pembelajaran memerlukan perhatian dari penanggung jawab sistem pendidikan secara terus menerus antara lain melalui fungsionalisasi supervisi pendidikan. Pelaksanaan supervisi pendidikan dengan strategi teknik yang sudah baku akan lebih baik bila fungsinya lebih fokus pada pengembangan karakter kejujuran guru dalam pembelajaran. Tugas seorang supervisor adalah untuk membantu, mendorong, dan memberikan keyakinan kepada guru bahwa proses belajar-mengajar dapat dan harus terus lebih baik. Kegiatan supervisi terlaksana melalui berbagai proses pemecahan masalah pengajaran dan bertujuan untuk meningkatkan efektivitas dan efisiensi proses belajar-mengajar. Supervisi merupakan bantuan kepada guru dalam perbaikan situasi belajar-mengajar, akan lebih baik hasilnya bila memfokuskan pada internalisasi karakter kejujuran pada diri guru dalam melaksanakan tugas pokok dan fungsinya di sekolah.
\end{abstract}

Kata kunci: Fungsionalisasi, Supervisi, Kejujuran, Guru, Pendidikan

Cara sitasi:

Kusnandi (2020). Fungsionalisasi Supervisi Pendidikan Untuk Membentuk Karakter Kejujuran Guru Dalam Peningkatan Kualitas Profesi Guru Dan Pembelajaran. Jurnal Wahana Pendidikan, 7 (1), 85-94. 


\section{PENDAHULUAN}

Harapan Negara dan masyarakat terhadap Sekolah sebagai lembaga pendidikan formal sangatlah tinggi. Kusnandi (2019) berpendapat bahwa "tujuan pendidikan yaitu membentuk manusia seutuhnya, bangsa yang tangguh, berakhlak mulia, bermoral, bertoleransi, bekerja sama, membentuk bangsa mempunyai jiwa patriotik, suka menolong sesama, bangsa yang dinamis dan mengawal kemajuan ilmu pengetahuan dan teknologi agar mengantarkan manusia Indonesia beriman dan bertaqwa kepada Alloh SWT". Sehingga sekolah diharapkan terus menerus meningkatkan kualitasnya agar dapat meluluskan sumber daya manusia yang berdaya guna bagi kemajuan bangsa. Kunci utamanya terletak pada peningkatan kualitas guru sebagai garda terdepan dalam pembelajaran, terutama karakter kejujuran harus menginternalisasi pada diri setiap guru.

Keberhasilan pembaharuan sekolah sangat ditentukan oleh gurunya, karena guru adalah pemimpin pembelajaran, fasilitator, dan sekaligus merupakan pusat inisiatif pembelajaran (Mulyasa, 2011:9). Aktifitas guru sebagai tenaga pengajar menjadi landasan dalam pencapaian tujuan pendidikan dalam sekolah, kegiatan yang dilakukan guru sangat berpengaruh terhadap pelaksanaan proses pembelajaran, hal ini dikarenakan seorang guru dalam berbagai kegiata menjadi seorang pemimpin serta pembimbing dalam kelas. Guru adalah pendidik profesional dengan tugas utama mendidik, mengajar, membimbing, mengarahkan, melatih, menilai, dan mengevaluasi peserta didik pada pendidikan anak usia dini jalur pendidikan formal, pendidikan dasar, dan pendidikan menengah. Dalam hal peningkatan mutu pendidikan merupakan tanggung jawan semua stakeholders pendidikan khususnya pendidik dan tenaga kependidikan, sebagaimana tuntutan UU RI Nomor 20 tahun 2003 Bab XI pasal 40 ayat 2b, "bahwa pendidik dan tenaga kependidikan berkewajiban: mempunyai komitmen secara profesional untuk meningkatkan mutu pendidikan".

Untuk melaksanakan tugas dan menjaga kualitas diri, guru memerlukan bantuan pembimbing agar dapat mengembangkan kemampuan profesionalnya terutama dalam mengelola proses pembelajaran, menjaga proses pembelajaran tetap berjalan dengan baik. Bimbingan dan perhatian tersebut diharapkan terjadi melalui fungsionalisasi supervisi pendidikan dalam membentuk karakter kejujuran guru untuk meningkatkan kualitas kinerja dan profesionalisme guru dalam proses pembelajaran. Hal ini sejalan dengan konsep supervisi dari Sergiovani dan Starrat dalam Mulyasa, (2003: 111), yaitu: "Supervisi merupakan suatu proses yang dirancang secara khusus untuk membantu para guru dalam mempelajari tugas sehari-hari di sekolah, agar dapat menggunakan pengetahuan dan kemampuannya untuk memberikan layanan yang lebih baik pada orang tua peserta didik dan sekolah, serta berupaya menjadikan sekolah sebagai masyarakat belajar yang lebih efektif.

Kepala sekolah dalam pelaksanaan supervisi pendidkan bukan hanya menilai kinerja seorang guru saja, tetapi semua kegiatan yang berhubungan dengan proses pembelajaran, yaitu supervisi akademik sebagai rangkaian kegiatan membantu guru mengembangkan kemampuannya mengelola proses belajar mengajar demi pencapaian tujuan pengajaran. Supervisi akademik akan lebih baik bila difungsikan untuk membentuk karakter kejujuran guru khususnya kejujuran akademik.

Walaupun tuntutan legalitas UU RI Nomor 20 Tahun 2003, bahwa guru harus memiliki empat kompetensi yaitu: 1) Kompetensi Pedagogik, 3) Kompetensi profesional, 3) Kompetensi sosial, dan 4) Kompetensi kepribadian, tetapi tidak semua guru memiliki kesempurnaan kompetensi tersebut, hal ini terlihat dari banyaknya guru-guru yang tidak dapat menjalankan tugasnya dengan baik, dalam perencanaan maupun pelaksanaan proses pembelajaran di sekolah, sehingga terjadi perbedaan yang signifikan hasil atau kualitas pendidikan yang dihasilkan oleh setiap guru. Dengan 
fungsionalisasi supervisi pendidikan, guru diharapkan lebih baik dan jujur dalam menciptakan situasi pembelajaran yang kondusif, mampu mengelola kelas, mampu menguasai materi pelajaran, menguasai teori belajar, dan terampil menerapkan berbagai metode dalam mendidik siswa dalam sekolah.

Fungsionalisasi supervisi pendidikan dalam membentuk karakter guru yang jujur dan profsional dalam pembelajaran masih menemukan banyak kendala, antara lain kesukaran kepala sekolah karena, terbatasnya kemampuan profesional, terbatasnya waktu, terbatasnya petunjuk pelaksanaan dan terbatasnya biaya. Selain itu Sagala (2000:45) mengatakan bahwa "Rendahnya profesi, prestasi, mutu proses dan hasil pembelajaran siswa, juga disebabkan oleh peran supervisi di sekolah di Indonesia menjadi lemah, kurang efesien dan efektif." Kusnandi (2017) berpendapat bahwa dalam menghadapi perubahan kehidupan di berbagai aspek yang semakin cepat dan semakin rumit, inovasi pendidikan harus menjadi prioritas penting karena pendidikan masih dijadikan penopang utama peningkatan kualitas sumber daya manusia. Oleh karena itu, supervisi harus dilaksanakan oleh orang yang memiliki kemampuan profesional dan memiliki visi sebagai agen inovasi pembelajaran dalam melakukan supervisi pendidikan dan pengajaran.

\section{METODA PENELITIAN}

Penelitian ini dilakukan secara kualitatif pada lima sekolah yang berlokasi di Ciamis, Tasikmalaya, dan Pangandaran sebagai tempat bekerja para mahasiswa Pascasarjana Unigal, Program Studi Administrasi Pendididkan, Konsentrasi Pendidikan Dasar, ketika mereka mengikuti perkuliahan Supervisi Pendidikan. Mereka diberi tugas melakukan penelitian di sekolah, bagaimana pelaksanaan supervisi pendidikan, apa hambatannya, bagaimana solusinya, dsb.

Data kegiatan supervisi pendidikan diperoleh melalui observasi, wawancara, dan studi pustaka. Hasil observasi dan wawancara oleh para mahasiwa dipresentasikan sebanyak empat kali di dalam perkuliahan, hingga ditemukan berbagai problematika supervisi pendidikan dalam pelaksanaan di sekolah. Kemudian problematika tersebut diidentifikasi untuk dibuat satu topik bahasan bagaimana agar supervisi pendidikan lebih inovatif, kreatif, dan fungsional dalam meningkatkan kualitas pembelajaran.

Dengan menganalisa laporan tugas mahasiswa yang dipresentasikan, dilakukan kajian pustaka untuk mendapatkan suatu konsep bagaimana meningkatkan fungsi supervisi pendidikan untuk menginternalisasi karakter kejujuran pada diri guru, selain melaksanakan tugas supervisi pendidikan sebagaimana SOP yang berlaku.

\section{HASIL DAN PEMBAHASAN}

\section{Fungsionalisasi Supervisi Pendidikan}

Fungsionalisasi maknanya adalah membuat sesuatu berfungsi sebagaimana seharusnya atau pemfungsionalan. Supervisi pendidikan adalah pembinaan yang berupa bimbingan atau tuntunan ke arah perbaikan situasi pendidikan pada umumnya dan peningkatan mutu pembelajaran pada khususnya. Fungsionalisasi supervise pendidikan adalah suatu upaya maksimal bagaimana agar kegiatan pembinaan dan tuntunan terhadap pendidik dan tenaga kependidikan dapat berfungsi secara optimal sesuai dengan juknis dan juklak atau SOP yang berlaku.

Berbagai ahli mengemukakan arti supervisi pendidikan baik secara etimologis, empiris, teoritis, maupun secara yuridis. Menurut Arikunto (2004: 4), "Supervisi yang berasal dari bahasa Inggris terdiri dari dua akar kata, yaitu super yang artinya "diatas" dan vision yang mempunyai arti 
"dilihat", maka secara keseluruhan supervisi diartikan sebagai "melihat dari atas", dengan pengertian itulah maka supervisi diartikan sebagai kegiatan yang dilakukan oleh pengawas dan kepala sekolah sebagai pejabat yang berkedudukan di atas atau lebih tinggi dari guru untuk melihat atau mengawasi pekerjaan guru ". Adam \& Dickey yang dikutip Sahertian, (2000: 17) berpendapat bahwa "supervisi adalah program yang berencana untuk memperbaiki pengajaran. Program itu pada hakikatnya adalah perbaikan hal belajar dan mengajar".

Dapat dikatakan bahwa supervisi memberikan bimbingan atau pelayanan profesional terhadap guru pelayanan professional yang dimaksud adalah bantuan dalam mengembangkan situasi pembelajaran ke arah yang lebih baik, pelayanan tersebut melalui pengarahan, bimbingan dan pengawasan terhadap guru dengan tujuan dapat meningkatkan kualitas serta prestasi guru, guru yang berkualitas dapat menjalankan tugas dan fungsinya dengan baik serta memiliki kompetensi yang tinggi.

\section{Prinsip Kegiatan Supervisi Pendidikan}

Kegiatan supervisi pendidikan merupakan bantuan terhadap guru dengan maksud untuk menjaga dan memelihara kualitas guru dalam proses pembelajaran di sekolah, karena itu kegiatan supervisi sangat penting bila menginginkan kualitas pendidikan yang baik di sekolah. Sahertian (2000: 19) mengemukakan tujuan supervisi adalah memberikan layanan dan bantuan untuk meningkatkan kualitas mengajar guru di kelas yang pada giliranya untuk meningkatkan kualitas belajar siswa. Arikunto (2004:40) mengemukakan bahwa supervisi bertujuan "memberikan bantuan teknis dan bimbingan kepada guru (dan staf sekolah yang lain) agar personil tersebut mampu meningkatkan kualitas kinerjanya, terutama dalam melaksanakan tugas, yaitu melaksanakan proses pembelajaran, selanjutnya apabila kualitas kinerja guru dan staf sudah meningkat, demikian pula mutu pembelajarannya, maka diharapkan prestasi belajar siswa juga akan meningkat. Pemberian bantuan pembinaan dan pembimbing tersebut dapat bersifat langsung ataupun tidak langsung kepada guru yang bersangkutan".

Supervisi pendidikan memiliki berbagai macam fungsi. Secara sederhana fungsi supervisi meliputi empat fungsi utama yaitu: "(1) fungsi penelitian, (2) fungsi penilaian, (3) fungsi perbaikan, dan (4) fungsi peningkatan" (Satori, 2006:5). Supervisi yang dilakukan berkaitan langsung dengan tugas profesional guru yaitu: merencanakan, melaksanakan, dan menilai pembelajaran serta melakukan umpan balik untuk perbaikan kulitas pembelajaran.

Dalam juklak dan juknis dari Dirjen Dikdasmen, terdapat beberapa prinsip yang harus diperhatikan dalam melakukan supervisi pendidikan yaitu:

1. Ilmiah (scientific), dimana dalam pelaksanaan supervisi hendakanya dilaksanakan secara ilmiah, hal ini berarti pelaksanaanya harus: (a) sistematis, taratur, terprogram dan terus-menerus, (b) objektif, berdasarkan pada data dan pengetahuan, (d) menggunakan instrumen (alat) yang dapat memberikan data/pengetahuan yang akurat, dapat dianalisa dan dapat mengukur ataupun menilai terhadap pelaksanaan proses pembelajaran.

2. Demokratis, dalam pelaksanaan supervisi hendaknya menjunjung tinggi azas musyawarah, memiliki jiwa kekeluargaan yang kuat serta menghargai dan sanggup menerima pendapat orang lain.

3. Kooperatif, dalam melaksanakan supervisi hendaknya dapat mengembangkan usaha bersama untuk situasi pembelajaran yang lebih baik.

4. Konstruktif dan kreatif, dalam pelaksanaan supervisi hendaknya dapat membina inisiatif guru serta mendorong untuk aktif dalam menciptakan situasi pembelajaran yang lebih baik. 


\section{Pelaksanaan Supervisi Pendidikan}

Pelaksanaan supervisi dilaksanakan oleh pelaku supervisi dan subjek yang akan disupervisi, pelaku supervisi adalah unsur yang paling dekat atau langsung terlibat dengan prestasi belajar siswa, yaitu: Pengawas, Kepala Sekolah, Wakil Kepala Sekolah bidang kurikulum atau akademik, wali kelas, petugas bimbingan dan konseling, serta petugas perpustakaan, sementara subjek supervisi adalah guru dan pegawai.

Sasaran utama supervisi pendidikan adalah untuk melakukan pembinaan terhadap guruguru agar dapat melakukan semua tugas dengan lebih baik. Sebagai supervisor harus mampu mengadakan pengendalian dan supervisi terhadap tenaga kependidikan khususnya guru dengan tujuan meningkatkan kemampuan profesi guru dan kualitas proses pembelajaran. Dalam pelaksanaan supervisi ada beberapa teknik supervisi yang dapat dipilih dan digunakan supervisor meliputi: 1) Kunjungan kelas, 2) Kunjungan sekolah, 3) Ujian dadakan, 4) Konfrensi kasus, 5) Observasi Dokumen, 6) Wawancara, 7) Angket, 8) Laporan.

Supervisi yang dilakukan kepala sekolah terhadap guru dalam juklak dan juknis dari Kemenag RI meliputi: (1) masalah wawasan dan kemampuan profesional guru, (2) masalah kehadiran dan aktivitas guru, (3) masalah persiapan mengajar guru, mulai dari analisa bahan mata pelajaran pelajaran, program tahunan, program semester, program satuan pelajaran, pembuatan mata pelajaran sampai dengan persiapan mengajar harian atau rencana pelaksanaan pembalajaran, (4) masalah pencapaian tujuan kurikuler dan pelaksanaan ekstrakurikuler, (5) penguasaan bahan ajar, (6) penggunaan metode pembelajaran, (7) penggunaan alata peraga/praktek, (8) pengaruh timbal balik pembelajaran, (10) penilaian hasi belajar pelajar, (8) tindak lanjut hasil penilaian pembelajaran mata pelajaran. (9) masalah kerjasama guru dengan pelajar, dengan sesama guru, tata usaha dan dengan kepala madrasah.

Pelaksanaan supervisi pendidikan di sekolah lebih menitikberatkan pada rutinitas dan formalitas, sebagai bentuk pelaksanaan tugas dan ada bukti laporan ke berbagai pihak yang berkepentingan dan harus mengikuti juklak, juknis, dan berbagai SOP yang berlaku. Tak sedikit guru lebih mementingkan laporan administratif yang rapi dan baik kepada supervisor daripada menyampaikan dan memperlihatkan secara jujur tentang pembelajaran yang telah dilaksanakannya. Sudah langka supervisor melakukan pengamatan langsung situasi pembelajaran di kelas agar dapat mengetahui secara obyektif tentang pembelajaran yang dilaksanakan guru. Supervisor lebih fokus pada laporan adminsitatif guru ketimbang realitas edukatif yang sebenarnya. Sulit bagi guru untuk berterus terang secara jujur tentang berbagai permasalahan pembelajaran kepada supervisor. Hal ini sangat membahayakan bagi pencapaian tujuan pendidikan, sebagaimana halnya seorang pasien yang tidak jujur kepada dokter yang akan mengobatinya, akan mengakibatkan kesalahan tindakan medis yang membahayakan kesehatan pasien tersebut.

\section{Upaya Meningkatkan Kualitas Supervisi Pendidikan}

Program-program supervisi hendaknya memberikan rangsangan terhadap terjadinya perubahan dalam kegiatan pengajaran. Perubahan - perubahan itu dapat dilakukan antara lain melalui berbagai usaha inovasi dalam pengembangan kurikulum serta kegiatan pendidikan dan pelatihan dalam jabatan untuk guru. Kepala sekolah harus menguasai langkah-langkah dalam pelaksanaan supervisi khususnya supervisi peggajaran beserta tujuannya. Supervisi merupakan suatu usaha untuk memberikan pelayanan perbaikan situasi mengajar belajar yang direncanakan secara hati-hati. Supervisi oleh kepala sekolah haruslah diarahkan untuk memberikan bantuan dan 
bimbingan serta pembinaan kepada guru-guru agar mereka mampu bekerja lebih baik dalam membimbing peserta didik.

Pada dasarnya Supervisi berkaitan dengan kemampuan kepala sekolah dalam memberikan arahan, bimbingan serta memberikan bantuan kepada guru-guru dalam mencapai kinerja yang dipersyaratkan bagi seorang guru. Indikator guru yang kinerjanya baik dan profesional dalam implementasi kurikulum antara lain mampu mendesain program pembelajaran, mampu melaksanakan proses pembelajaran dan mampu melakukan penilaian hasil belajar siswa, serta mampu menindaklanjutinya untuk perbaikan kualitas pembelajaran.

Dalam pelaksanaan supervisi pendidikan, sikap kooperatif dan kejujuran guru yang ditunjukan dalam fase perencanaan tetap masih diperlukan, malahan perlu ditingkatkan. Kesediaan guru untuk diobservasi dan dianalisis perilaku mengajarnya, serta kesediaan untuk berdialog dengan supervisor harus terus dikembangkan, sehingga guru dapat memperoleh manfaat sebesar-besarnya dari proses supervisi pendidikan. Sebagai upaya peningkatan kualitas supervisi pendidikan dapat dilakukan uji kompetensi pengawas sebgai supervisor meliputi enam kompetensi, yaitu: Kompetensi kepribadian, kompetensi supervisi manajerial, kompetensi supervisi akademik, kompetensi evaluasi pendidikan, kompetensi penelitian pengembangan, dan kompetensi sosial.

Berdasarkan petunjuk Kementrian Agama yang membidangi pengelolaan pendidikan, untuk meningkatkan kualitas supervisi pendidikan, kepala sekolah perlu memenuhi kompetensi umum maupun kompetensi khusus. Kompetensi umum meliputi: (1) Bertindak demokratis, bersifat terbuka/transparan, menghormati pendapat orang lain, mampu berkomunikasi dengan baik dan menjalin kerjasama dengan berbagai pihak terkait, (2) memiliki kepribadian yang menarik dan simpatik serta mudah bergaul, (3) Bersifat ilmiah dalam segala hal serta memiliki prinsip mau terus belajar, (4) Memiliki dedikasi tinggi serta layak pada tugas dan jabatannya, (5) Menghindarkan diri dari sifat-sifat tercela, (6) Memandang guru dan seluruh staf sekolah sebagai mitra kerja, bukan sebagai bawahan. Adapaun kemampuan khusus seorang supervisor adalah: (1) Memiliki pengetahuan tentang manajemen pendidikan secara umum dan manajemen sekolah secara khusus, yang meliputi manajemen personil, manajemen bahan mata pelajaran dan manajemen operasional, (2) Memiliki pengetahuan tentang supervisi pendidikan, yang meliputi tujuan dan sasaran, teknikteknik, langkah-langkah dan prinsip-prinsip dasar supervisi pendidikan, (3) Menguasai subtansi bahan mata pelajaran pengawasan pendidikan, yang meliputi kurikulum, proses pembelajaran, kesimpulan dan lain-lain, (4) Menguasai subtansi bahan mata pelajaran supervisi teknik manajemen, yang antara lain: adminstrasi sekolah, adminstrasi kepegawaian, adminstrasi kurikulum, pengelolaan perpustakaan, laboratorium dan sebagainya, (5) Memiliki kemampuan berkomunikasi, membina dan memberi contoh-contoh tentang pelaksanaan kegiatan belajar, mengajar yang baik, (6) Memiliki kemampuan mediator antara guru dengan guru, antara seluruh stap sekolah dengan instansi terkait, dan lain-lain, (7) Memiliki kemampuan membimbing guru dalam hal perolehan angka kredit dan membuat karya tulis/ilmiyah, (8) Harus bekerja sesuai dengan rencana dan tujuan yang telah ditetapkan, (9) Harus memiliki kepatuhan terhadap peraturan perundang-undangan yang berlaku dan harus menjunjung tinggi kode etik jabatan.

Kepala sekolah membuat rencana, program dan pelaksanaan supervisi pendidikan yang telah disepakati bersama dengan guru. Kegiatan supervise pendidikan diawali dengan perencanaan supervisi yang matang, agar supervisi dapat dijalankan dengan baik, kepala sekolah harus terlebih dahulu membuat rencana dan program supervise. Kemampuan menyusun program supervisi pendidikan harus diwujudkan dalam penyusunan program supervisi kelas, pengembangan program 
supervisi untuk kegiatan ekstra kurikuler, program pengembangan supervisi perpustakaan, laboratorium dan ujian. Kemampuan melaksanakn program supervisi pendidikan harus diwujudkan dalam pelaksanaan program supervisi klinis, program supervisi non klinis, dan program supervisi kegiatan ekstrakurikuler. Sedangkan kemampuan memanfaatkan hasil supervisi pendidikan harus meningkatkan prestasi kerja tenaga kependidikan.

Supervisi harus bersumber pada kondisi masyarakat. Sebenarnya sekolah harus mampu mengubah masyarakat agar menjadi masyarakat yang demokratis. Dalam masyarakat demokratis setiap orang berkesempatan dan kemampuan untuk menstimulasi usaha-usaha kreativitas dan mengubah ke arah perbaikan. Kepala sekolah sebagai supervisor berfungsi membantu, mendorong, menstimulasi tiap anggota untuk bekerja bersama. Seorang supervisor dalam melakukan tanggung jawabnya, ia harus mampu mengembangkan potensi kreativitas dari orang yang dibina melalui cara mengikutsertakan orang lain untuk berpartisipasi bersama. Supervisor dapat memberikan saran secara terbuka tetapi bersahabat tentang masalah-masalah yang dikemukakan dalam penilaian, dan guru harus bersifat terbuka untuk menerimannya, maka akan terjadi proses saling memperkaya antara guru dengan supervisor dalam usaha meningkatkan kualitas pembelajaran.

\section{Pembentukan Karakter Kejujuran Guru}

Kejujuran (honesty) merupakan induk segala kebaikan dan ketidakjujuran (dishonesty) atau kebohongan adalah akar dari segala kejahatan dan dosa yang berkepanjangan dan beranak pinak. Pembohong akan membela diri dengan kebohongan-kebohongan berikutnya. Pendidikan merupakan finish destination untuk menghasilkan manusia yang berkarakter jujur, dan pendidik utamanya adalah guru, bagaimana mungkin peserta didik akan memiliki karakter jujur jika gurunya tidak memiliki karakter jujur. Guru adalah manusia yang pantas digugu dan ditiru, guru kencing berdiri murid kencing berlari beegitulah ungkapan sebuah peribahasa. Guru juga manusia yang perlu terus menerus mendapat bimbingan dan tuntunan terutama dari para supervisor pendidikan yang professional, jujur dan bertaqwa kepadaAlloh SWT.

Guru yang jujur tak akan pernah merugikan siapapun, senantiasa menjaga amanah (kepercayaan), yang sudah pasti akan mmiliki rasa tanggung jawab yang tinggi dengan menjalankan tugas dan kewajibannya dengan sepenuh hati dengan dilandasi sikap yang berkeadilan. Kejujuran termasuk dalam nilai moral dan nilai spiritual, dalam sila Kemanusiaan yang adil dan beradab dan dalam kitab suci Al-Qur'an Alloh telah memerintahkan manusia untuk jujur dalam perkataan. "Hai orang-orang yang beriman bertaqwalah kamu kepada Alloh dan katakanlah perkataan yang benar, niscaya Alloh memperbaiki bagimu amal-amalmu, dan mengampuni bagimu dosa-dosamu. Dan barang siapa mentaati Alloh dan Rasul-Nya, maka sesungguhnya ia telah mendapat kemenangan yang besar" (QS Al-Ahzab: 70-71). Perintah jujur itu special diberikan kepada orang yang beriman, sebagaimana perintah berpuasa. Guru yang jujur sangatlah beruntung karena Alloh menjanjikan sesuatu yang pasti yaitu akan diperbaiki amal perbuatannya (seluruh aktifitasnya termasuk kegiatan pembelajaran), dan akan dibersihkan segala kesalahannya serta akan mendapatkan kesuksesan yang luar biasa (kemenangan yang besar).

Selain empat kompetensi yang harus dimiliki guru (Pedagogik, profesional, kepribadian, dan sosial), karakter kejujuran harus menginternalisasi dalam pelaksanaan tugas pembelajaran. Guru yang jujur akan menjadi teladan bagi peserta didik dan akan dijauhkan dari perselisihan dengan rekan sejawat dan orang-orang yang berada di sekelilingnya. Ketidakjujuran hanya akan menjadi lahan permusuhan, "Dan katakanlah kepada hamba-hamba-Ku: Hendaklah mereka mengucapkan 
perkataan yang lebih baik (benar). Sesungguhnya syaitan (suka) menimbulkan perselisihan diantara mereka. Sesungguhnya syaitan itu adalah musuh yang nyata bagi manusia" (QS Al-Israa:53).

Kejujuran merupakan perilaku Rasulullah SAW sehingga beliau diberikan gelar Al-Amin, karena itulah Beliau berhasil sukses luar biasa mendidik para sahabatnya menjadi manusia yang taqwa dan mendapat jaminan masuk surga, tanpa melalui jenjang pendidikan berstrata sebagaimana sekarang. "Sesungguhnya telah ada pada (diri) Rasulullah itu suri teladan yang baik bagimu (yaitu) bagi orang yang mengharap (rahmat) Alloh dan (kedatangan) hari kiamat dan dia banyak menyebut Alloh" (QS Al-Ahzab:21). Jika guru ingin sukses dalam pembelajaran maka harus mencontoh Rasulullah SAW, bagaimana strategi pendidikan yang telah dipraktekannya.

\section{KESIMPULAN}

Kualitas proses belajar mengajar sangat dipengaruhi oleh kualitas kinerja guru, untuk itu sumber daya guru itu perlu terus menerus bertumbuh dan berkembang agar dapat melakukan fungsinya secara professional, mendorong guru-guru untuk terus menerus belajar menyesuaikan diri dengan perkembangan ilmu pengetahuan dan teknologi.

Dalam meningkatkan kemampuan guru dalam melaksanakan proses belajar mengajar, memerlukan perhatian dari penanggung jawab sistem pendidikan secara terus menerus. Dalam pelaksanaannya supervisi dapat dilakukan melalui berbagai pendekatan yang sesuai dengan SOP yang berlaku, supervisi pengajaran merupakan pekerjaan profesional, yang menuntut persyaratan sebagaimana layaknya pekerjaan profesional yang lain.

Tugas seorang supervisor bukanlah untuk mengadili tetapi untuk membantu, mendorong, dan memberikan keyakinan kepada guru bahwa proses belajar-mengajar dapat dan harus diperbaiki. Usaha supervisi tidak akan berhasil apabila tidak ada keinginan untuk kerjasama dan tidak ada sikap kooperatif baik dari yang dibantu yaitu guru sendiri maupun supervisor (kepala sekolah). Guru hendakna secara aktif memberikan masukan kepada supervisor tentang masalah yang dihadapi dalam mengajar. supervisor tidak mempunyai tujuan untuk mencari kesalahan, tetapi memberikan balikan tentang kelemahan dan kekuatan guru dalam melaksanakan tugasnya.

Supervisi mengembangkan dan meningkatkan kinerja profesional guru sehingga guru tersebut dapat berkembang dalam pekerjaannya. Kegiatan supervisi dilaksankan melalui berbagai proses pemecahan masalah pengajaran. Tujuannya adalah untuk meningkatkan efektivitas dan efisiensi pembelajaran. Supervisi merupakan bantuan kepada guru dalam perbaikan situasi belajarmengajar, supervisi pendidikan meliputi supervisi terhadap pengajaran maupun komponen pendukungnya. Supervisi pengajaran merupakan kegiatan yang berhubungan langsung dengan pengajaran tetapi tidak langsung dengan siswa.

\section{REKOMENDASI}

Perlu dilakukan peningkatan kualitas supervisi pendidikan dengan memperluas fungsinya untuk membentuk karakter kejujuran guru baik secara akademik, moral, maupun spiritual. Dengan guru yang berkarakter jujur diharapkan kualitas pembelajaran akan semakin meningkat dan akan menghasilkan lulusan yang berkarakter jujur. Kejujuran merupakan mata uang yang berlaku di seluruh dunia dan akan lebih mengangkat harkat dan martabat guru di manapun ia berada. 


\section{UCAPAN TERIMAKASIH}

Terimakasih kepada Fakultas Keguruan dan Ilmu Pendidikan Universitas Galuh Ciamis yang telah memfasilitasi publikasi penerbitan artikel dan juga pada berbagai pihak yang telah membantu pelaksanaan penelitian.

\section{DAFTAR PUSTAKA}

Arikunto, Suharsimi. (2004). Dasar-dasar Supervisi. Jakarta: PT Rineka Cipta International Education (2011) News Letter, December, 2011

Kementrian Agama Republik Indonesia. Al-Qur'an Berkamus Tematis Ayat Akhlak \& Ibadah. PT Widya Cahaya.

Kusnandi. (2017). Model Inovasi Pendidikan Dengan Strategi Implementasi Konsep "Dare To Be Different". Jurnal Wahana Pendidikan 4 (1), 132-144

Kusnandi. (2019). Mengartikulasikan Perencanaan Pendidikan Di Era Digital. Jurnal Wahana Pendidikan 6 (1), 1-14

Mulyasa, E. (2003). Kurikulum Berbasis Kompetensi. Bandung: Remaja Rosda Karya.

Mulyasa, E. (2011). Menjadi Guru Profesional Menciptakan Pembelajaran Kreatif dan Menyenangkan. Bandung: PT Remaja Rosdakarya.

Sagala, S. (2000). Administrasi pendidikan kontemporer. Bandung: Alfabeta.

Sagala, S. (2012). Kemampuan Profesional Guru dan Tenaga Kependidikan: Pemberdayaan guru, tenaga kependidikan, dan masyarakat dalam manajemen sekolah. Alfabeta.

Sahertian, Piet A. (2000). Konsep Dasar danTteknik Supervisi Pendidikan dalam Rangka Pengembangan Sumber Daya Manusia. Jakarta: Rineka Cipta

Satori, Dj. (2006) Supervisi Akademik dan Penjaminan Mutu dalam Pendidikan Persekolahan. Koleksi Materi Perkuliahan Supervisi Pendidikan IPA SPs Bandung. Tidak diterbitkan

Satori, Dj. (2016). Pengawasan dan Penjaminan Mutu Pendidikan. Bandung: Alfabeta

Undang-undang RI Nomor 20 Tahun 2003 Tentang Sistem Pendidikan Nasional. Jakarta: Sinar Grafika

Undang-undang RI Nomor. 14 tahun 2005 tentang Guru dan Dosen. 
Jurnal Wahana Pendidikan, 7(1), 85-94, Januari 2020

P-ISSN: 2355-2425 dan E-ISSN : 2715-6796 